\title{
Air Quality Impacts Due to Construction of LWR Waste Management Facilities
}

URS Company

155 Bovet Road

San Mateo, CA 94402

June 1977

Prepared for Pacific Northwest Laboratory under Agreement B-3266-A-L

Pacific Northwest Laboratory Operated for the U.S. Department of Energy by Battelle Memorial Institute 


\title{
NOTICE
}

This report was prepared as an account of work sponsored by the United States Government. Neither the United States nor the Department of Energy, nor any of their employees, nor any of their contractors, subcontractors, or their employees, makes any warranty, express or implied, or assumes any legal liability or responsibility for the accuracy, completeness or usefulness of any information, apparatus, product or process disclosed, or represents that its use would not infringe privately owned rights.

The views, opinions and conclusions contained in this report are those of the contractor and do not necessarily represent those of the United States Government or the United States Department of Energy.

\author{
PACIFIC NORTHWEST LABORATORY \\ operated by \\ BATTELLE \\ for the \\ UNITED STATES DEPARTMENT OF ENERGY \\ Under Contract EY-76-C-06-1830
}

\begin{tabular}{|c|c|c|}
\hline \multicolumn{3}{|c|}{$\begin{array}{c}\text { Printed in the United States of Am } \\
\text { Available from } \\
\text { National Technical Information Ser } \\
\text { United States Department of Comn } \\
5285 \text { Port Royal Road } \\
\text { Springfield, Virginia } 22151\end{array}$} \\
\hline Price: & Printed Copys & \# Microfic \\
\hline & - Pages & $\begin{array}{c}\text { NTIS } \\
\text { Selling Price }\end{array}$ \\
\hline & $001-025$ & $\$ 4.00$ \\
\hline & $026-050$ & $\$ 4.50$ \\
\hline & $051-075$ & $\$ 5.25$ \\
\hline & $076-100$ & $\$ 6.00$ \\
\hline & $101-125$ & $\$ 6.50$ \\
\hline & $126-150$ & 57.25 \\
\hline & $151-175$ & $\$ 8.00$ \\
\hline & $176-200$ & $\$ 9.00$ \\
\hline & $201-225$ & 59.25 \\
\hline & $226-250$ & $\$ 9.50$ \\
\hline & $251-275$ & $\$ 10.75$ \\
\hline & $276-300$ & 511.00 \\
\hline
\end{tabular}


PNL-3026

$U C-11$

\section{0}

AIR QUALITY IMPACTS DUE TO CONSTRUCTION OF LWR WASTE MANAGEMENT FACILITIES

URS Company

155 Bovet Road

San Mateo, CA 94402

June 1977

Prepared for

Pacific Northwest Laboratory under Agreement B-3266-A-L

Pacific Northwest Laboratory Operated for the U.S. Department of Energy By Battelle Memorial Institute 
TABLE OF CONTENTS

Section

Page

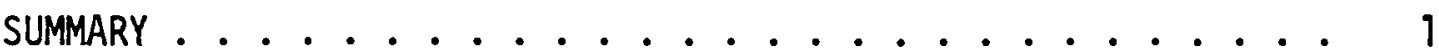

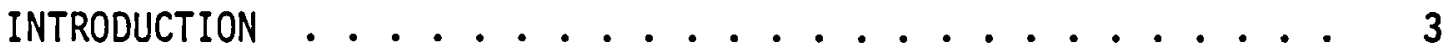

EMISSION INVENTORY - REFERENCE ENVIRONMENT . . . . . . 4

Labor Force Assumptions . . . . . . . . . . . . . . 4

Motor Vehicle Emissions .............. 6

Construction Emissions .................. 12

Summary .................. 15

AIR QUALITY IMPACTS - REFERENCE ENVIRONMENT . . . . . 17

Particulates and Sulfur Dioxide ........... 17

Carbon Monoxide ................. 20

Hydrocarbons and Oxides of Nitrogen . . . . . . . . . 22

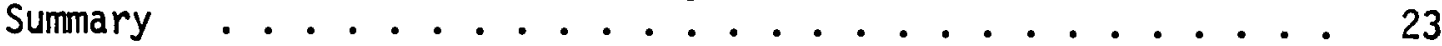

EMISSION INVENTORY - BOOM-TOWN ENVIRONMENT . ...... 24

Labor Force Assumptions . . . . . . . . . . . . 24

Motor Vehicle Emissions . . . . . . . . . . . . . . 24

Emissions Due to Induced Development .......... 29

Construction Emissions ....................... 30

Summary .................... 30

AIR QUALITY IMPACTS - BOOM-TOWN ENVIRONMENT ........ 32

Particulates and Sulfur Dioxide . . . . . ..... 32

Carbon Monoxide ................. . . 36

Hydrocarbons and Nitrogen oxides ................ 37

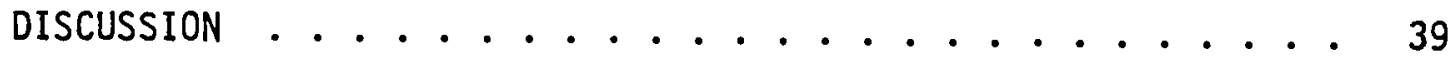

Comparison of Facility Emissions .......... 40

Comparison of Diffusion Potential in Various Geographical $\cdots$

REFERENCE LIST .......................... 48 


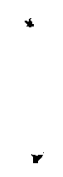

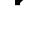

. 


\section{LIST OF FIGURES}

Figure No.

$\underline{\text { Page }}$

Figure 1. Suspended Particulate Concentrations Due to Construction Site Activity .........

Figure 2. Suspended Particulate Concentrations Due to Construction Site Activity and Induced Growth . .

Figure 3. Sulfur Dioxide Concentrations Due to Construction Site Activity and Induced Growth .........

Figure 4. Location of Sites for Diffusion Potential Comparison 


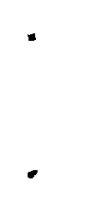


LIST OF TABLES

Table No.

Page

1 Distribution of Local Labor Force - Reference Environment .............. 5

Daily Distance Traveled by Construction Workers Reference Environment . . . . . . . . . 7

Fraction of Total Vehicles in Use by Model Year . . . 8

4 Mileage By Vehicle Type and Model Year - Reference Environment (miles)............ 9

5 Annual Motor Vehicle Emissions - Reference Environment - Automobiles ............ 10

6 Annual Motor Vehicle Emissions - Reference Environment - Light Trucks ............ 11

7 Emissions Due to Propane Combustion ........ 14

8 Annual Emissions Due to Diesel and Gasoline-Powered Equi pment $(\mathrm{kg}) \ldots \ldots . \ldots 15$

9 Summary of Reference Environment Emissions (kg/year) 16

10 Summary of Reference Environment Impacts ...... 23

11 Daily Distance Traveled - Boom-Town Environment . . . 25

12 Mileage by Vehicle Type and Model Year - Boom-Town Environment (miles) ............. 26

13 Annual Motor Vehicle Emissions - Boom-Town Environment - Automobiles ............. 27

14 Annual Motor Vehicle Emissions - Boom-Town Environment - Light Trucks ............. 28

15 Residential Heating Emission Factors ...... 29

16 Annual Emission Due to Residential Space and Process Heating (kg/year)............ 30

17 Summary of Boom-Town Environment Emissions ( $\mathrm{kg} /$ year) 31

18 Summary of Boom-Town Environment Impacts ...... 38

19 Comparison of Facility Characteristics ...... 41

20 Comparison of Facility Emissions ........ 43

21 Comparison of $x / Q$ Values at Eight Sites...... 44

22 Comparison of Diffusion Potential and Maximum Expected Concentrations for Various Geographical Areas . . . 44 


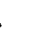


SUMMARY

Air quality impacts of construction activities and induced housing growth as a result of construction activities were evaluated for four possible facilities in the LWR fuel cycle: a fuel reprocessing facility, fuel storage facility, fuel fabrication plant, and a nuclear power plant. Since the fuel reprocessing facllity would require the largest labor force, the impacts of construction of that facility were evaluated in detail.

Two environments were considered in the analysis -- a reference environment, assumed to be typical of a midwest site near a metropolitan area; and a boom-town environment, assumed to be typical of an isolated site in the southwest. Very little relocation of construction workers was assumed for the reference environment while 100 percent relocation was assumed for the boom-town environment.

An emission inventory identified the major source of particulates as fugitive dust generated at the construction site. The major sources of sulfur dioxide were found to be the hypothesized boom-town's new residences through fuel oil combustion for space heating. The major source of carbon monoxide, hydrocarbons, and nitrogen oxides is induced motor vehicle traffic due to the labor force. All emissions calculations were based on worst case assumptions.

Impacts on suspended particulate concentrations were found to be significant on and downwind from the actual construction site. The calculations indicate that the national annual standard for suspended particulates could be exceeded in those areas. Significant impacts would not occur off the property of the fuel reprocessing facility, however. 
Impacts on $\mathrm{SO}_{2}$ concentrations would occur within the hypothesized boom-town due primarily to residential space heating. For the environment examined, however, the increases are not expected to endanger the national standards for $\mathrm{SO}_{2}$. Impacts on $\mathrm{CO}, \mathrm{HC}$, and $\mathrm{NO}_{x}$ would also occur. The magnitude of the impacts would be sma11, however, and are not expected to approach any national standards.

Potential impacts due to other waste management facilities were compared to the fuel reprocessing facility based on the labor force required, the amount of fuel to be consumed during construction, and the land area required. All facilities were found to have lesser impacts on ambient pollutant concentrations.

A comparison of diffusion potential $(x / Q)$ at various geographical areas was made. The comparison showed that many areas had lower diffusion potential than the area (midwest) evaluated. The Zimmer, Ohio site in particular could produce maximum annual concentrations nearly six times as high as those estimated previously. This would cause very high particulate concentrations near the construction site, al though impacts off the property would still be small. $\mathrm{SO}_{2}$ concentrations within the proposed boom-town would also be much higher, exceeding the national annual standard. 
INTRODUCTION 


\section{INTRODUCTION}

This report presents an assessment of the air quality impact resulting from construction of various waste management facilities in ERDA's Light Water Reactor Fuel Cycle Program. The assessment was completed in support of the Generic Environmental Impact Statement on the LWR waste management facilities.

Pollutant emissions considered in the assessment include emissions from construction equipment and facilities, fugitive dust, and secondary emissions due to induced growth. Two induced growth scenarios were examined -- one assuming little or no relocation of construction workers and another assuming nearly 100 percent relocation (i.e., a boom-town). The former scenario is termed the reference environment and uses parameters (i.e., meteorological data, population data) defined for a typical location in the United States. The latter scenario is termed the boomtown environment and is assumed to be located in a rural, isolated location in the southwestern U.S.

To account for the uncertainties in the construction force and source terms, a worst case approach to the study was taken. Maximum estimates of construction force size, obtained from Pacific Northwest Laboratory (PNL), were used in the analysis along with worst case emission factors. Standard dispersion models were employed using the derived source terms and meteorological data for a reference environment provided by PNL.

The waste management faclitity with the largest construction force (fuel processing facility) was used to determine source terms for the detalled impact analysis. Other facilities were compared to the fuel reprocessing facility to determine the magnitude of impacts expected. Also, the meteorological data set defined for the reference environment was used, although data could differ widely in other locations. For this reason, a comparison of diffusion potential for various sites nationwide was made. 
EMISSIONS INVENTORY - REFERENCE ENVIRONMENT 


\section{EMISSION INVENTORY - REFERENCE ENVIRONMENT}

\section{Labor Force Assumptions}

The labor force considered for the reference environment analys is is 2,700, or the peak force during the third year of construction. Forty percent of this labor force will come from the county in which the project is constructed, while 60 percent of the force will be from outside the county but within a 50 mile radius, according to Battelle Human Affairs Research Center estimates. For the purpose of this analysis, it is assumed that little or no new development or influx of people will occur in the area. While some influx of people is inevitable, it is expected that the influx will be inconsequential in terms of air quality impacts.

The distribution of the labor force is assumed to be as follows: there are five towns within 10 miles of the construction site as defined by the reference environment; it was assumed that the 40 percent local component of the labor force would be distributed among those towns proportional to their population (i.e., town A, which has 27 percent of the population within the 10 mile radius will be assigned 11 percent of the labor force). Thus, the distribution of the local labor force between the towns and the distances from the towns to the construction site are shown in Table 1. 
Table 1

Distribution of Local Labor Force - Reference Environment

\begin{tabular}{lcc}
\hline & Labor Force Residents & $\begin{array}{c}\text { Distance from Site } \\
\text { (miles) }\end{array}$ \\
\hline Town A & 288 & 8 \\
Town B & 58 & 4 \\
Town C & 144 & 5 \\
Town D & 158 & 10 \\
Town E & 432 & 10 \\
\hline
\end{tabular}


The remaining 60 percent of the labor force is assumed to be out of the local county but within a 50 mile radius. The bulk of this labor force is assumed to originate from a large town (pop. 40,000) 20 miles northwest of the site and from a metropolitan area (pop. 1,800,000) 30 miles southeast of the site. If the 60 percent of the labor force were distributed between these two population centers according to population, and weighted according to distance from the site, 50 would originate from the town to the northwest of the site and the other 1,570 would originate from the metropolitan area to the southeast of the site.

\section{Motor Vehicle Emissions}

Since the labor force is assumed to reside in the area, the important impact to consider in connection with the labor force is the impact caused by increased motor vehicle traffic. In order to do this, the vehicle trips generated by the labor force must be estimated. Using trip generation data presented in a number of references (BAAPCD, 1975; NCHRP, 1966; WSITE, 1967; EPA, 1976), it was decided to use a trip generation factor of six trips per dwelling unit. The analysis assumes that each laborer represents one dwelling unit and that the dwelling units are a mix of single and multifamily dwellings.

Two of the six trips are accounted for by the laborer's commute to the project site and their length is therefore a direct reflection of that distance. The remaining four trips are generated either by the laborer after working hours or by his immediate family and each are assumed to be 5 miles in length.

The non-work trips are taken to be local trips only and are therefore of short length. These trips would already be accounted for since the labor force is already in the area. For the purpose of this analysis, however, the emissions generated by all the trips are considered to obtain a worst case condition. 
Based on the above assumptions, the daily distance traveled by the labor force and their families are presented in Table 2.

Table 2

Daily Distance Traveled by Construction Workers - Reference Environment (miles)

\begin{tabular}{ccc}
\hline Work Trave1 & Non-Work Travel & Total \\
\hline 114,516 & 54,000 & 168,516 \\
\hline
\end{tabular}

NOTE: The above mileage estimates reflect a worst case estimate since it is assumed that each laborer would drive a lone car (i.e., no car-pooling).

The anticipated annual mileage traveled by the labor force and their immediate families can be combined with estimates of vehicle mix, model year, and emission factors to produce an estimate of total motor vehicle emissions from non-construction related activities for the calendar year 1980. All of the estimates presented in the following paragraphs either come directly from or are in part based on Supplement No. 5 of the Compilation of Air Pollutant Emission Factors (EPA, 1975b).

Vehicle mix is important because the emissions originating from light-duty vehicles (automobiles) and light-duty trucks vary substantially (note: it is assumed that non-construction emissions will be due entirely to these two types of vehicles). No specific data on the probable mix of autos/trucks for the reference area are available. However, it is expected that though the project area is in a rural setting, the probable vehicle mix will approximate that of an urban environment -- 64 percent autos/36 percent trucks (EPA, 1975b). The basis for this approximation is the tendency of construction workers to frequently own and use light-duty trucks as their primary means of 
transport. Thus, a higher number of trucks would be expected then would normally be found in a suburban/rural environment (NOTE: EPA, 1975b lists the auto/truck $m 1 x$ for a suburban setting at $88 / 12$ ). The urban environment, on the other hand, has a higher percentage of trucks due to the frequent use of delivery trucks in an urban area. For these reasons, it is expected that the vehicle mix listed by EPA (1975b) for the urban environment more closely approximates that which will occur as a result of this project. Thus, the following analysis assumes a vehicle mix of 64 percent automobiles and 36 percent light trucks.

In estimating vehicle emissions, it is also important to know the model years involved (since older models give off more emissions). Using data presented in EPA (1975b), the breakdowns in Table 3 of model years are expected in 1980 for both automobile and light truck travel resulting from the project.

Table 3

Fraction of Total Vehicles

In Use By Model Year

\begin{tabular}{lcc}
\hline $\begin{array}{l}\text { MODEL } \\
\text { YEAR }\end{array}$ & AUTOMOBILES & LIGHT TRUCKS \\
\hline 1980 & 0.052 & 0.022 \\
1979 & 0.070 & 0.035 \\
1978 & 0.068 & 0.035 \\
1977 & 0.068 & 0.035 \\
1976 & 0.065 & 0.030 \\
1975 & 0.061 & 0.027 \\
1974 & 0.056 & 0.027 \\
1973 & 0.049 & 0.023 \\
1972 & 0.041 & 0.019 \\
1971 & 0.031 & 0.015 \\
1970 & 0.021 & 0.013 \\
1969 & 0.015 & 0.009 \\
1968 & 0.009 & 0.006 \\
Pre-1968 & 0.032 & 0.060 \\
& 0.64 & 0.36 \\
\hline
\end{tabular}

Source: EPA, 1975b. 
The above fractional breakdown can then be used to calculate the number of miles driven by each vehicle type and model year (based on the earlier estimate of the total number of miles driven). Such a calculation is presented in Table 4 both on a daily and annual basis.

Table 4

Mileage By Vehicle Type and Model

Year - Reference Environment (mi les)

\begin{tabular}{|c|c|c|c|c|}
\hline & \multicolumn{2}{|c|}{ AUTOMOBILES } & \multicolumn{2}{|c|}{ LIGHT TRUCKS } \\
\hline & Daily & Annually & Daily & Annually \\
\hline $\begin{array}{l}1980 \\
1979 \\
1978 \\
1977 \\
1976 \\
1975 \\
1974 \\
1973 \\
1972 \\
1971 \\
1970 \\
1969 \\
1968 \\
\text { Pre-1968 }\end{array}$ & $\begin{array}{r}8,763 \\
11,796 \\
11,459 \\
11,459 \\
10,953 \\
10,279 \\
9,437 \\
8,257 \\
6,909 \\
5,224 \\
3,539 \\
2,528 \\
1,517 \\
5,393\end{array}$ & $\begin{array}{r}3,198,000 \\
4,305,000 \\
4,183,000 \\
4,183,000 \\
3,998,000 \\
2,752,000 \\
3,445,000 \\
3,014,000 \\
2,522,000 \\
1,907,000 \\
1,292,000 \\
922,700 \\
553,700 \\
1,968,000\end{array}$ & $\begin{array}{r}3,707 \\
5,898 \\
5,898 \\
5,898 \\
5,055 \\
4,550 \\
4,550 \\
3,876 \\
3,202 \\
2,528 \\
2,191 \\
1,517 \\
1,011 \\
10,110\end{array}$ & $\begin{array}{r}1,353,000 \\
2,153,000 \\
2,153,000 \\
2,153,000 \\
1,845,000 \\
1,661,000 \\
1,661,000 \\
1,415,000 \\
1,169,000 \\
922,600 \\
799,600 \\
553,000 \\
369,000 \\
3,690,000\end{array}$ \\
\hline
\end{tabular}

NOTE: The annual miles traveled assume that construction would proceed 365 days/year.

The above mileages can now be multiplied by emission factors given for each vehicle type and model year in Appendix $D$ of Supplement No. 5 for the Compilation of Air Pollutant Emissions Factors (EPA, 1975b). The emission factors were calculated using speed, temperature, and percentage of cold start/hot start operations factors. An average speed for all trips of $25 \mathrm{mph}$ was assumed, an average annual temperature of $45^{\circ} \mathrm{F}$ was assumed, and it was assumed that 20 percent of all vehicle operations would be from a cold start. The emission factors and the resultant emissions for each vehicle type are presented in Tables 5 and 6. 
Table 5

Annual Motor Vehicle Emissions

- Reference Environment

Automobiles

\begin{tabular}{|c|c|c|c|c|c|c|}
\hline \multirow[b]{2}{*}{$\begin{array}{l}\text { Model } \\
\text { Year. }\end{array}$} & \multicolumn{2}{|c|}{ Carbon Monoxide } & \multicolumn{2}{|c|}{ Hydrocarbons } & \multicolumn{2}{|c|}{ Oxides of Nigrogen } \\
\hline & $\begin{array}{l}\text { Emission } \\
\text { Factors } \\
\text { (g/mi le) }\end{array}$ & $\begin{array}{l}\text { Annual } \\
\text { Emissions } \\
(\mathrm{Kg})\end{array}$ & $\begin{array}{l}\text { Emission } \\
\text { Factors } \\
\text { (g/mile) }\end{array}$ & $\begin{array}{l}\text { Annual } \\
\text { Emissions } \\
(\mathrm{Kg})\end{array}$ & $\begin{array}{l}\text { Emission } \\
\text { Factors } \\
\text { (g/mile) }\end{array}$ & $\begin{array}{c}\text { Annual } \\
\text { Emissions } \\
(\mathrm{Kg})\end{array}$ \\
\hline 1980 & 5.2 & 16,630 & 1.0 & 3,200 & 0.3 & 960 \\
\hline 1979 & 5.8 & 24,970 & 2.3 & 9,900 & 0.4 & 1,720 \\
\hline 1978 & 6.4 & 26,770 & 2.4 & 10,040 & 0.5 & 2,090 \\
\hline 1977 & 21.9 & 91,610 & 4.6 & 19,240 & 2.9 & 12,130 \\
\hline 1976 & 23.6 & 94,350 & 5.0 & 19,990 & 4.7 & 18,790 \\
\hline 1975 & 25.3 & 94,920 & 5.4 & 20,260 & 4.9 & 18,380 \\
\hline 1974 & 51.9 & 178,790 & 7.2 & 24,800 & 5.2 & 17,910 \\
\hline 1973 & 54.1 & 163,060 & 7.5 & 22,600 & 5.4 & 16,270 \\
\hline 1972 & 56.2 & 141,740 & 7.8 & 19,670 & 5.5 & 13,870 \\
\hline 1971 & 75.3 & 143,600 & 9.5 & 18,120 & 5.2 & 9,920 \\
\hline 1970 & 77.9 & 100,640 & 12.0 & 15,500 & 5.2 & 6,720 \\
\hline 1969 & 88.4 & 81,570 & 11.5 & 10,610 & 6.1 & 5,630 \\
\hline 1968 & 87.6 & 48,500 & 12.6 & 6,980 & 5.2 & 2,880 \\
\hline Pre-1968 & 104.9 & 206,440 & 12.6 & 24,800 & 4.0 & 7,870 \\
\hline TOTAL & 36 & $1,413,600$ & 5.7 & 225,700 & 3.4 & $\overline{135,140}$ \\
\hline
\end{tabular}

NOTE: Emission factor in Total column is weighted average of all factors -all emission factors from EPA, $1975 b$. 
Table 6

Annual Motor Vehicle Emissions -

Reference Environment

Light Trucks

\begin{tabular}{|c|c|c|c|c|c|c|}
\hline \multirow[b]{2}{*}{$\begin{array}{l}\text { Model } \\
\text { Year }\end{array}$} & \multicolumn{2}{|c|}{ Carbon Monoxide } & \multicolumn{2}{|c|}{ Hydrocarbons } & \multicolumn{2}{|c|}{ Oxides of Nitrogen } \\
\hline & $\begin{array}{l}\text { Emission } \\
\text { Factors } \\
\text { (g/mile) }\end{array}$ & $\begin{array}{c}\text { Annual } \\
\text { Emissions } \\
(\mathrm{Kg})\end{array}$ & $\begin{array}{l}\text { Emission } \\
\text { Factors } \\
\text { (g/mile) }\end{array}$ & $\begin{array}{l}\text { Annual } \\
\text { Emissions } \\
(\mathrm{Kg})\end{array}$ & $\begin{array}{l}\text { Emission } \\
\text { Factors } \\
\text { (g/mile) }\end{array}$ & $\begin{array}{c}\text { Annual } \\
\text { Emissions } \\
(\mathrm{Kg})\end{array}$ \\
\hline 1980 & 18.3 & 24,760 & 2.1 & 2,840 & 3.1 & 4,190 \\
\hline 1979 & 20.2 & 39,400 & 4.1 & 4,520 & 3.2 & 6,670 \\
\hline 1978 & 22.1 & 43,490 & 4.4 & 8,830 & 3.2 & 6,890 \\
\hline 1977 & 58.9 & 47,580 & 8.4 & 9,470 & 6.8 & 6,890 \\
\hline 1976 & 61.7 & 108,670 & 9.0 & 15,500 & 7.0 & 12,550 \\
\hline 1975 & 64.5 & 102,480 & 9.5 & 14,950 & 7.3 & 11,630 \\
\hline 1974 & 59.4 & 107,130 & 8.4 & 15,780 & 6.7 & 12,130 \\
\hline 1973 & 61.7 & 84,050 & 8.8 & 11,890 & 7.0 & 9,480 \\
\hline 1972 & 64.0 & 71,130 & 9.0 & 10,290 & 6.4 & 8,180 \\
\hline 1971 & 77.9 & 59,050 & 10.8 & 8,300 & 6.2 & 5,900 \\
\hline 1970 & 77.9 & 62,290 & 12.6 & 8,640 & 6.2 & 4,960 \\
\hline 1969 & 94.1 & 43,080 & 12.5 & 6,970 & 6.4 & 3,430 \\
\hline 1968 & 92.8 & 34,240 & 15.1 & 5,570 & 5.9 & 2,180 \\
\hline Pre-1968 & 132.5 & 488,930 & 20.6 & 76,010 & 5.0 & 18,450 \\
\hline TOTAL & 70.8 & $1,316,300$ & 10.7 & 199,600 & 6.0 & 113,530 \\
\hline GRAND TOTAL & 47.8 & $2,729,900$ & 7.4 & 425,300 & 4.3 & 248,670 \\
\hline
\end{tabular}

NOTE: Emission factor in Total column is weighted average of all factors -all emission factors from EPA, $1975 \mathrm{~b}$. 


\section{Construction Emtssions}

The major sources of emissions resulting from the actual construction of the project facilities include emissions from the concrete batching plant, from ground-clearing operations, and from fuel consumption by construction machinery.

\section{Concrete Batching}

Emissions resulting from the batching plant will arise both from the sand and gravel processing which must preceed the batching operation and batching operation itself. An expected 153,000 cubic yards of concrete will be produced (1 cubic yard weighs 4,000 pounds). This concrete will be comprised of sand, gravel and cement with sand/gravel making up 80 percent of each cubic yard of concrete (i.e., 3,265 pounds out of 4,000 [EPA, 1972]). Emission factors for sand and gravel processing place the particulate emissions at $0.1 \mathrm{lb} /$ ton of product.

In order to produce the 249.770 tons of sand and gravel necessary to subsequently produce 153,000 cubic yards of concrete, the particulate emissions from sand and gravel processing will be 24,980 pounds or $11,330 \mathrm{~kg}$. It is assumed, for purposes of the worst case analysis, that these emissions would occur in a one-year period.

Emissions from the actual batching operation will depend to a large part on the amount of control which is exerted upon it. However, for the purpose of this "worst-case" analysis it is assumed that no control is exerted and that all emissions occur within a one-year period. The emission factor for an uncontrolled batching operation is $0.21 \mathrm{~b} / \mathrm{yd}^{3}$ concrete (EPA, 1972). Applying the factor to the volume of concrete to be used yields batching emissions of 30,600 pounds or 13,880 kilograms. Therefore total emissions due to concrete processing is $25,210 \mathrm{~kg}$ annualiy. 
Ground Clearing (Fugitive Dust)

Project construction will involve the clearing and subsequent construction of project facilities upon 60 acres of land. Based on PEDCo (1974) heavy construction operations will result in particulate emissions of 1.2 tons/acre/month of activity or 14.4 tons/acre annually. For the site under consideration (60 acres), this would result in an annual emission of 864 tons or 783,800 kilograms. The estimate assumes that the bulk of land would be clear and exposed for a year period.

The emission factor is based on empirical measurements, taken at actual construction sites. Although emissions would depend on such factors as soil silt content, soil moisture, and wind speed, quantitative relationships have not been established. 'Therefore the average factor has been used in this analysis.

Fue 1 Consumption

Construction machinery used in the project's construction will consume approximately

and $1,500,000$ liters of propane $7,600,000$ liters of diesel fuel $9,800,000$ liters of gasoline

Emission factors for propane combustion are contained in Supplement No. 3 (EPA, 1974), while emission factors for diesel and gasoline combustion in heavy construction equipment is found in Supplement No. 4 (EPA, 1975a).

The above consumption is spread over a four year period. In order to determine peak annual consumption (i.e., the "worst-case" situation), the peak manpower of the third year was compared to the project's total manpower requirements. This comparison indicated that 43 percent of the total 
manpower was required in the third year. It was then assumed that construction equipment requirements and their subsequent fuel consumption will be:

$$
\begin{gathered}
647,140 \text { liters of propane } \\
\text { and } \quad 3,278,800 \text { liters of diesel fue } 1 \\
4,228,000 \text { liters of gasoline }
\end{gathered}
$$

If the propane used is assumed to have a sulfur content of 0.16 grams per $100 \mathrm{ft}^{3}$ gas vapor ( 0.366 grains per $10^{3}$ i iters), the the emissions shown in Table 7 can be estimated.

\section{Table 7}

Emissions Due to Propane Combustion

Carbon Monoxide

0.23

Hydrocarbons

0.084

Oxides of Nitrogen

1.3

841

Sulfur oxides

$0.015^{*}$

Particulates

0.22

*S equals 0.366 grams $/ 10^{3}$ liters

Source: EPA, 1974.

Emissions due to diesel and gasoline combustion, however, are dependent upon the type of construction (heavy-duty) machinery involved. Unfortunately, no data exist as to the machinery types involved in this project. Thus, for the purpose of this analysis, both an average emission factor for several discrete equipment types and an emission factor for a miscellaneous category of construction machines were studied (EPA, 1975a, Supplement No. 4). In order to get a "worst-case" analysis, the higher of the two emission factors was taken from each pollutant category and used in the subsequent emission inventory. The emission factors used are listed in Table 8. 
Peak annual emissions resulting from the emission factors are also listed in Table 8.

Table 8

Annual Emissions Due to Diesel and

Gasol ine-Powered Equipment

$(\mathrm{kg})$

\begin{tabular}{lccccc}
\hline & \multicolumn{2}{c}{$\begin{array}{c}\text { Diese1-Powered } \\
\text { Equipment }\end{array}$} & \multicolumn{2}{c}{$\begin{array}{c}\text { Gasol ine-Powered } \\
\text { Equipment }\end{array}$} \\
\cline { 2 - 6 } & $\begin{array}{c}\text { Emission } \\
\text { Factor }\end{array}$ & $\begin{array}{c}\text { Annuat } \\
\text { Emissions }\end{array}$ & \multicolumn{2}{c}{$\begin{array}{c}\text { Emission } \\
\text { Factor }\end{array}$} & $\begin{array}{c}\text { Annuat } \\
\text { Emissions }\end{array}$ \\
\hline Carbon monoxide & 11.4 & 37,380 & 475 & $2,008,300$ \\
Hydrocarbons & 4.16 & 13,640 & 16.6 & 70,180 \\
Oxides of Nitrogen & 59.2 & 194,100 & 14.1 & 59,610 \\
Sulfur oxides & 3.74 & 12,260 & 0.633 & 2,680 \\
Particulates & 3.61 & 11,840 & 0.887 & 3,750 \\
\hline
\end{tabular}

Source: EPA, 1975a.

Summary

A11 emissions calculated for the reference environment analysis are summarized in Table 9. The emissions are separated into two categories -- growth inducement (motor vehicle) emissions and construction emissions. 


\section{Table 9}

Summary of Reference Environment Emissions $(\mathrm{kg} / \mathrm{yr})$

\begin{tabular}{lrc}
\hline \multicolumn{1}{c}{ Pollutant } & $\begin{array}{c}\text { Construction } \\
\text { Emissions }\end{array}$ & $\begin{array}{c}\text { Growth Inducement } \\
\text { Emissions } \\
\text { (Motor Vehicle) }\end{array}$ \\
\hline Carbon monoxide & $2,045,829$ & $2,729,900$ \\
Hydrocarbons & 83,874 & 425,300 \\
Oxides of Nitrogen & 254,551 & 248,670 \\
Sulfur dioxide & 14,941 & -- \\
Particulates & 824,742 & -- \\
\hline
\end{tabular}




\author{
.
}


AIR QUALITY IMPACTS - REFERENCE ENVIRONMENT 


\section{AIR QUALITY IMPACTS - REFERENCE ENVIRONMENT}

\section{Particulates and Sulfur Dioxide}

The major source of particulate and sulfur dioxide emissions during the construction phase of the project will be on-site construction activities. Fugitive dust was estimated to be the major source of particulates; construction vehicles were estimated as the major source of $\mathrm{SO}_{2}$ emissions. Although motor vehicles will emit a small amount of particulate and sulfur dioxide, the emissions will be spread out over such a large area that their impact on ambient air quality concentrations will be negligible.

The construction of the fuel reprocessing plant is expected to require approximately 60 acres of cleared land. In order to spatially distribute the estimated emissions, it was assumed that the fugitive dust and all construction vehicle emissions would be uniformly distributed over the 60 acre area. The concrete batching plant was assumed to be a point source within the 60 -acre area.

In order to estimate the impact on ambient air quality, the Climatological Dispersion Model (CDM) was used (EPA, 1973). The model determines long-term (annual) quasi-stable pollutant concentrations at specified ground level receptors using average emission rates from point and area sources and a joint frequency distribution of wind direction, wind speed, and stability for the annual period. Variable input parameters were specified as follows: meteorological data was that taken from the reference environment, all emisstons were assumed to occur during the daytime, a grid size of 500 meters was utilized with a receptor specified at the midpoint of each grid, the area source was assumed to occupy one grid square $\left(250,000 \mathrm{~m}^{2} \approx 60\right.$ acres $)$ and be at ground level, 
the point source was assumed to be at 5 meters with essentially no plume rise, and $\mathrm{SO}_{2}$ was assumed to have a half life (decay rate) of 3 hours while particulates were given a large half life.

The result of the particulate model run is presented in Figure 1. The area source is marked by the cross-hatched grid and the point source is marked by an "X." The isopleth values are particulate concentrations expressed as the $\mu \mathrm{g} / \mathrm{m}^{3}$ annual geomteric mean. The model output is an annual arithmetic mean concentration with those concentrations converted to annual geometric mean concentrations by statistical methods developed by Larsen (EPA, 1971) and air quality data from a typical midwest region (MPCA, 1974 and 1975). The concentrations presented are concentrations caused by construction activities only (i.e., no background is included).

The maximum impact expected off the immediate construction site is a $30 \mathrm{\mu g} / \mathrm{m}^{3}$ annual geometric mean increase. The maximum areal extent of the impact occurs about $3 \mathrm{~km}$ from the site boundary to the southeast, where a $5 \mathrm{\mu g} / \mathrm{m}^{3}$ increase in particulate concentrations occurs. Particulate impacts at distances further than $3 \mathrm{~km}$ from the site become negligible. Since the total site property would encompass about 6,000 acres, or $24 \mathrm{~km}^{2}$, the bulk of the particulate impact will occur on facility property. The nearest population is 4 miles northwest of the site, as defined by the reference environment, therefore no particulate concentration increases are expected at any of the nearby towns.

Particulate concentrations were found to exceed $100 \mu \mathrm{g} / \mathrm{m}^{3}$ annual geometric mean on the actual construction site. The particulate impacts both on and off the site will persist as long as the ground is cleared for construction. If that period is not over a year, the annual geometric mean will not be as high as estimated, but will be high during the construction period. 


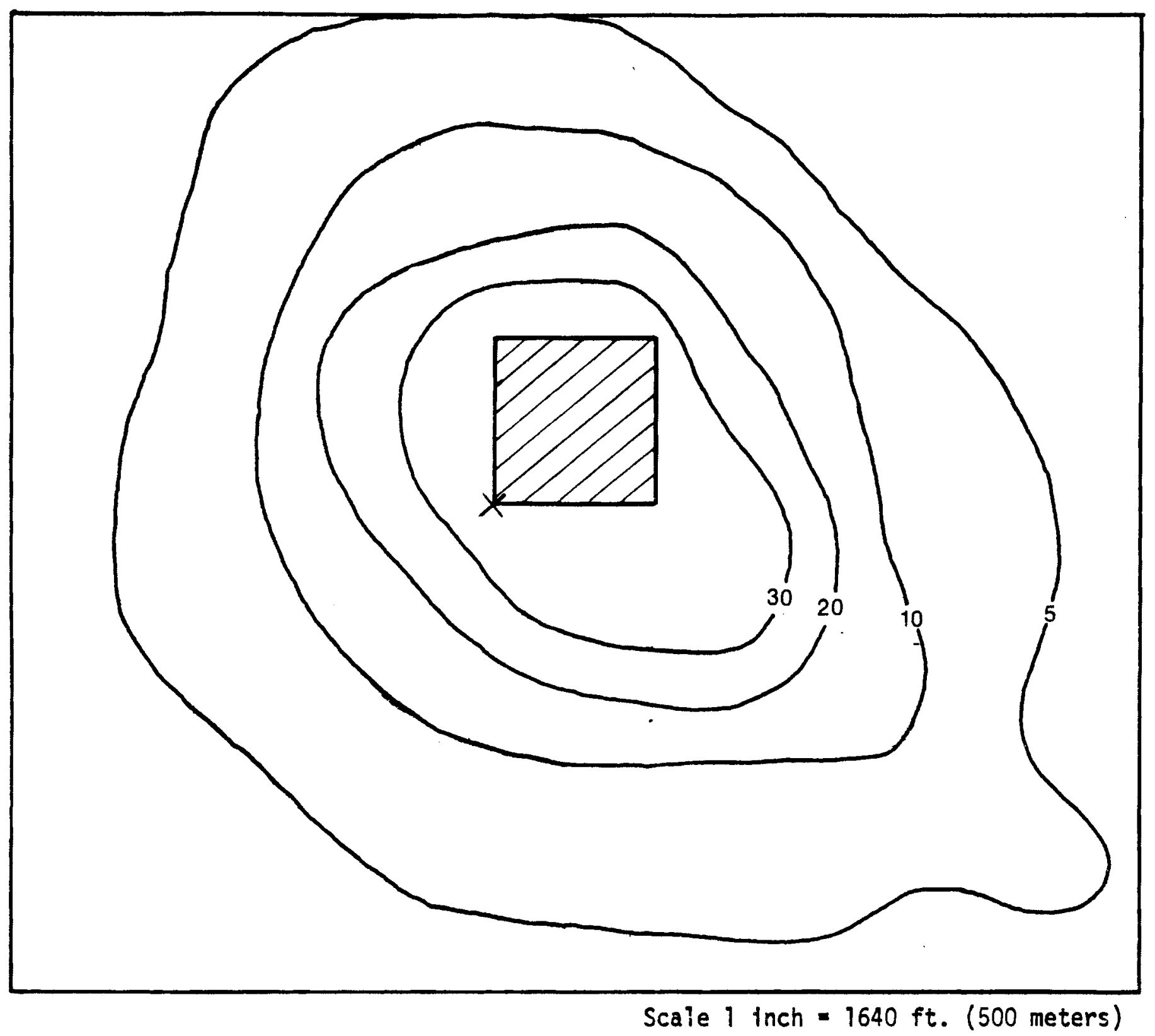

Figure 1.

Suspended Particulate Concentrations

Due to Construction Site Activity

(Annual Geometric Mean in $\mu \mathrm{g} / \mathrm{m}^{3}$ ) 
A typical annual geometric mean background concentration for the reference environment is $40 \mu \mathrm{g} / \mathrm{m}^{3}$ (MPCA, 1973 and 1974). Given that background concentration, the $100 \mu \mathrm{g} / \mathrm{m}^{3}$ annual geomteric mean increase on the construction site would cause the national standard of $75 \mu \mathrm{g} / \mathrm{m}^{3}$ to be exceeded. The concentrations off the site will not cause the standard to be exceeded. Some states have annual ambient air quality standards for particulate at $60 \mu \mathrm{g} / \mathrm{m}^{3}$, including New Hampshire, New Mexico, Ohio, Washington, California, Delaware, and Hawaij. This standard would be exceeded off the construction site but not off the property.

The results of the $\mathrm{SO}_{2}$ model runs show little or no impact on $\mathrm{SO}_{2}$ ambient concentrations. The highest estimated $\mathrm{SO}_{2}$ concentration occurred on the construction site itself -- a $7 \mu \mathrm{g} / \mathrm{m}^{3}$ annual average. This is sma 11 compared to the $80 \mu \mathrm{g} / \mathrm{m}^{3}$ national standard for $\mathrm{SO}_{2}$. Short-term concentrations would also be well below their applicable standards.

\section{Carbon Monoxide}

The primary source of carbon monoxide is motor vehicles and construction equipment. Motor vehicle traffic to the site will be originating from a large area; therefore it will be diffused over most of the area. To assess the worst case $C O$ concentration, it was assumed that the entire 2,700-person labor force would converge on the construction site during a 1 -hour period on a single roadway, i.e., an access roadway to the construction site.

An emission factor of $47.8 \mathrm{grams} / \mathrm{mile}$ was used to assess the impact of motor vehicles, which is based on the same assumptions as were used previously to estimate total $\mathrm{CO}$ emissions (Table 5). In order to estimate the impact on ambient air quality, a line source diffusion model developed by the California Department of Transportation (CALTRANS, 1972) was utilized. Early morning worst case assumptions of F stability 
(as defined by Pasqui11), a 1 meter/second wind speed, and a wind direction that is $22.5^{\circ}$ from the highway alignment were considered.

An initial estimate was made within the mechanical mixing cell, or the volume of air over the highway where turbulent mixing is influenced primarily by the movement of vehicles. A 1-hour CO concentration of $12.7 \mathrm{ppm}$ was estimated within the cell. This concentration is well below the national 1-hour ambient air quality standard of $35 \mathrm{ppm}$. Onehour $\mathrm{CO}$ concentrations 100 meters downwind from the roadway were estimated to be about one-half of the mixing cell concentrations. The 8hour $\mathrm{CO}$ concentration would be much less than the estimated 1-hour since there would be only a small amount of traffic during the bulk of any 8hour period, and since variable meteorological conditions would better disperse emissions. Therefore, while there will be co concentration increases near roadways traveled by motor vehicles to the site, they will be small in relation to ambient air quality standards.

Construction equipment will emit a large amount of $\mathrm{CO}$ during the time that they are operating. In order to estimate the impact on ambient air quality of these emissions, it was assumed they are evenly distributed over a 60 acre $\left(.25 \mathrm{~km}^{2}\right)$ area. The diffusion from this area source was estimated using a virtual point source technique, where the area is treated as a source having an initial horizontal standard deviation and a virtual distance is defined that will give the initial standard deviation. Using this technique, and assuming worst case daytime atmospheric conditions of D stability and a 1 meter/second wind speed, concentration estimates were made at the downwind boundary of the area source. A maximum 1-hour CO concentration of $9 \mathrm{ppm}$ was estimated. Using a relationship developed by Turner (EPA 1970) of concentration vs. sampling time, the 8-hour $\mathrm{CO}$ concentration would be about $6 \mathrm{ppm}$. Both concentrations are below the national standard, al though the latter 8hour concentration approaches the 9 ppm Federal standard. 
CO concentration increases due to both motor vehicles and construction equipment could therefore be sizeable near the construction site, although standards should not be exceeded. Co impacts in the nearest population centers will be negligible due to the construction activity.

\section{Hydrocarbons and Oxides of Nitrogen}

Hydrocarbon and oxides of nitrogen emissions will result from both motor vehicles and construction equipment. Neither pollutant lends itself well to estimation of impacts through diffusion modeling; the national hydrocarbon standard is for non-methane hydrocarbon only and is not meant for source impact evaluation but for planning purposes, and the oxides of nitrogen standard is for nitrogen dioxide $\left(\mathrm{NO}_{2}\right)$ whereas the bulk of emissions are nitric oxide (NO). Therefore it was decided that a comparison of total emissions generated by the construction force and construction activity with existing emissions in the area would serve as the most useful estimate of the impact. Of particular concern is the potential for formation of secondary pollutants, notably photochemical oxidant.

The total hydrocarbon emissions generated by both motor vehicle traffic and construction equipment was estimated to be $509,420 \mathrm{~kg}$ annually. Total nitrogen oxide emissions were estimated at $503,220 \mathrm{~kg}$ annually. These emissions would occur within about a 30 mile radius of the construction site.

In order to compare the construction-related emissions with existing emissions, an existing area must be selected. A rural air quality control region, near a large metropolitan area in the midwest, was selected for the comparison. Emissions were obtained from a state annual air quality report (MPCA, 1975). The total hydrocarbon emissions were $22,797,450 \mathrm{~kg}$ annually and the total nitrogen oxide emissions were 
$15,715,590 \mathrm{~kg}$ annually. Comparing project emissions with regional emissions yields 2.2 percent for hydrocarbon and 3.2 percent for nitrogen oxides. Both fractions are small, especially considering that the region is a rural area with ifttle or no hydrocarbon, nitrogen oxide, or oxidant problems. Therefore, the magnitude of emissions caused by construction activities should cause no significant amblent pollutant concentration increases in the region.

Summary

Table 10 summarizes the maximum expected air quality impacts due to construction and growth inducement.

Table 10

Summary of Reference Environment Impacts

\begin{tabular}{|c|c|c|}
\hline Pollutant & $\begin{array}{l}\text { Maximum Expected } \\
\text { Impact }\end{array}$ & Location \\
\hline Carbon monoxide & $12.7 \mathrm{ppm}-1 \mathrm{hr}$. & $\begin{array}{l}\text { Road entrance to construc- } \\
\text { tion site }\end{array}$ \\
\hline Sulfur dioxide & $\mu \mathrm{g} / \mathrm{m}^{3}$ annual mean & Construction site \\
\hline \multirow[t]{2}{*}{ Particulates } & $\mu \mathrm{g} / \mathrm{m}^{3}$ annua $\mathrm{l}$ & Construction site \\
\hline & $\mu \mathrm{g} / \mathrm{m}^{3} \stackrel{\text { geometric }}{\text { mean }}$ & $\begin{array}{l}\text { Off construction site; on } \\
\text { property }\end{array}$ \\
\hline Hydrocarbon & $\begin{array}{l}2.2 \% \text { emission in- } \\
\text { crease }\end{array}$ & County-wide \\
\hline Oxides of Nitrogen & $\begin{array}{l}3.2 \% \text { emission in- } \\
\text { crease }\end{array}$ & County-wide \\
\hline
\end{tabular}


EMISSION INVENTORY - BOOM-TOWN ENVIRONMENT 
EMISSION INVENTORY - BOOM-TOWN ENVIRONMENT

\section{Labor Force Assumptions}

The labor force considered for the boom-town environment analysis is 2,700, the same force considered for the reference environment analysis. According to Battelle Human Affairs Research Center estimates, a large portion of the labor force would migrate to the area. Two major sources of emissions in connection with the labor force are evaluated; the emissions due to induced motor vehicle traffic and emissions due to induced development (i.e., additional dwelling units).

Motor Vehicle Emissions

For the purpose of this analysis, it was assumed that virtually all of the labor force will be located in one town approximately 5 miles from the site. The vehicle trips generated by the labor force were estimated using a factor of six trips per dwelling unit per day, the same figure used for the previous reference environment analysis. As before, the analysis assumes that each laborer represents one dwelling unit and that the dwelling units are an equal mix of single- and multi-family dwellings.

Two of the six trips are accounted for by the laborer's commute to the project site and their length is therefore related to that distance. The remaining four trips are generated either by the laborer after working hours or by his immediate family and each are assumed to be 5 miles in length. The non-work trips are assumed to be primarily local trips; hence the relatively short trip length. 
Based on the above assumptions, the daily distance traveled by the labor force and their families are presented in Table 11.

Table 11

Daily Distance Traveled - Boom-Town Environment (miles)

\begin{tabular}{ccc}
\hline Work Trave1 & Non-Work Trave1 & Tota 1 \\
\hline 27,000 & 54,000 & 81,000 \\
\hline
\end{tabular}

The anticipated mileage traveled can be combined with estimates of vehicle mix, model year, and emission factors to produce an estimate of total motor vehicle emissions from nonconstruction-related activities for the year 1980. Vehicle mix (automobiles vs trucks) and distribution of model years were estimated previously for the reference environment analysis (Table 2). The same parameters will be assumed for this analysis. The number of miles driven by each vehicle type and model year vehicle is estimated in Table 12.

The mileage in Table 12 can be multiplied by emission factors to obtain total vehicle emissions. The same assumptions applying to emission factors that were used in the reference environment analysis are used in this analysis. The resultant emissions for each vehicle type are presented in Tables 13 and 14. 
Table 12

Mileage by Vehicle Type and

Model Year - Boom-Town Environment

(miles)

\begin{tabular}{lrrrr}
\hline & \multicolumn{2}{c}{ Automobiles } & \multicolumn{2}{c}{ Light } \\
Year & Daily & Annual & Daily & Annual \\
\hline 1980 & 4,237 & $1,547,000$ & 1,793 & 654,000 \\
1979 & 5,704 & $2,082,000$ & 2,852 & $1,041,000$ \\
1978 & 5,541 & $2,022,000$ & 2,852 & $1,041,000$ \\
1977 & 5,541 & $2,022,000$ & 2,852 & $1,041,000$ \\
1976 & 5,296 & $1,933,000$ & 2,444 & 892,000 \\
1975 & 4,971 & $1,814,000$ & 2,200 & 803,000 \\
1974 & 4,563 & $1,665,000$ & 2,200 & 803,000 \\
1973 & 3,993 & $1,457,000$ & 1,874 & 684,000 \\
1972 & 3,341 & $1,219,000$ & 1,548 & 565,000 \\
1971 & 2,526 & 922,000 & 1,222 & 446,000 \\
1970 & 1,711 & 625,000 & 1,660 & 387,000 \\
1969 & 1,222 & 446,000 & 734 & 268,000 \\
1968 & 734 & 268,000 & 489 & 178,000 \\
Pre-1968 & 2,608 & 952,000 & 4,889 & $1,784,000$ \\
\hline
\end{tabular}

NOTE: The annual miles traveled assume that construction would proceed 365 days/year. 
Table 13

Annual Motor Vehicle Emissions - Boom-Town Environment Automobiles

\begin{tabular}{|c|c|c|c|c|c|c|}
\hline \multirow[b]{2}{*}{$\begin{array}{l}\text { Model } \\
\text { Year }\end{array}$} & \multicolumn{2}{|c|}{ Carbon Monoxide } & \multicolumn{2}{|c|}{ Hydrocarbons } & \multicolumn{2}{|c|}{ Oxides of Nitrogen } \\
\hline & $\begin{array}{l}\text { Emission } \\
\text { Factors } \\
\text { (g/mile) }\end{array}$ & $\begin{array}{c}\text { Annuat } \\
\text { Emissions } \\
(\mathrm{Kg})\end{array}$ & $\begin{array}{l}\text { Emission } \\
\text { Factors } \\
\text { (g/mile) }\end{array}$ & $\begin{array}{c}\text { Annual } \\
\text { Emissions } \\
(\mathrm{kg})\end{array}$ & $\begin{array}{l}\text { Emission } \\
\text { Factors } \\
\text { (g/mile) }\end{array}$ & $\begin{array}{c}\text { Annual } \\
\text { Emissions } \\
(\mathrm{Kg})\end{array}$ \\
\hline 1980 & 5.2 & 8,044 & 1.0 & 1,547 & 0.3 & 464 \\
\hline 1979 & 5.8 & 12,075 & 2.3 & 4,788 & 0.4 & 833 \\
\hline 1978 & 6.4 & 12,940 & 2.4 & 4,853 & 0.5 & 1,011 \\
\hline 1977 & 21.9 & 44,282 & 4.6 & 9,301 & 2.9 & 5,864 \\
\hline 1976 & 23.6 & 45,619 & 5.0 & 9,665 & 4.7 & 9,085 \\
\hline 1975 & 25.3 & 45,894 & 5.4 & 9,796 & 4.9 & 8,889 \\
\hline 1974 & 51.9 & 86,414 & 7.2 & 11,988 & 5.2 & 8,658 \\
\hline 1973 & 54.1 & 78,823 & 7.5 & 10,927 & 5.4 & 7,868 \\
\hline 1972 & 56.2 & 68,508 & 7.8 & 9,508 & 5.5 & 6,704 \\
\hline 1971 & 75.3 & 69,427 & 9.5 & 8,759 & 5.2 & 4,794 \\
\hline 1970 & 77.9 & 48,687 & 12.0 & 7,500 & 5.2 & 3,250 \\
\hline 1969 & 88.4 & 39,426 & 11.5 & 5,129 & 6.1 & 2,721 \\
\hline 1968 & 87.6 & 23,477 & 12.6 & 3,377 & 5.2 & 1,394 \\
\hline $\begin{array}{l}\text { Pre- } \\
1968\end{array}$ & 104.9 & 99,865 & 12.6 & 11,995 & 4.0 & 3,808 \\
\hline TOTAL & 36 & 683,480 & 5.7 & 109,130 & 3.4 & 65,340 \\
\hline
\end{tabular}

NOTE: Emission factor in Total column is weighted average of all factors. 
Table 14

Annual Motor Vehicle Emissions - Boom-Town Environment

Light Trucks

\begin{tabular}{|c|c|c|c|c|c|c|}
\hline \multirow[b]{2}{*}{$\begin{array}{l}\text { Model } \\
\text { Year }\end{array}$} & \multicolumn{2}{|c|}{ Carbon Monoxide } & \multicolumn{2}{|c|}{ Hydrocarbons } & \multicolumn{2}{|c|}{ Oxides of Nitrogen } \\
\hline & $\begin{array}{l}\text { Emission } \\
\text { Factors } \\
\text { (g/mile) }\end{array}$ & $\begin{array}{l}\text { Annuat } \\
\text { Emissions } \\
\text { (Kg) }\end{array}$ & $\begin{array}{l}\text { Emission } \\
\text { Factors } \\
\text { (g/mile) }\end{array}$ & $\begin{array}{l}\text { Annua } \\
\text { Emissions } \\
(\mathrm{Kg})\end{array}$ & $\begin{array}{l}\text { Emission } \\
\text { Factors } \\
\text { (g/mile) }\end{array}$ & $\begin{array}{l}\text { Annual } \\
\text { Emtssions } \\
(\mathrm{Kg})\end{array}$ \\
\hline 1980 & 18.3 & 11,968 & 2.1 & 1,373 & 3.1 & 2,027 \\
\hline 1979 & 20.2 & 21,028 & 4.1 & 4,268 & 3.2 & 3,331 \\
\hline 1978 & 22.1 & 23,006 & 4.4 & 4,580 & 3.2 & 3,331 \\
\hline 1977 & 58.9 & 61,315 & 8.4 & 8,744 & 6.8 & 7,079 \\
\hline 1976 & 61.7 & 55,036 & 9.0 & 8,028 & 7.0 & 6,244 \\
\hline 1975 & 64.5 & 51,793 & 9.5 & 7,268 & 7.3 & 5,862 \\
\hline 1974 & 59.4 & 47,698 & 8.4 & 6,745 & 6.7 & 5,380 \\
\hline 1973 & 61.7 & 42,203 & 8.8 & 6,019 & 7.0 & 4,788 \\
\hline 1972 & 64.0 & 36,160 & 9.0 & 5,085 & 6.4 & 3,616 \\
\hline 1971 & 77.9 & 34,743 & 10.8 & 4,817 & 6.2 & 2,765 \\
\hline 1970 & 77.9 & 30,147 & 12.6 & 4,876 & 6.2 & 2,399 \\
\hline 1969 & 94.1 & 25,219 & 12.5 & 3,350 & 6.4 & 1,715 \\
\hline 1968 & 92.8 & 16,518 & 15.1 & 2,688 & 5.9 & 1,050 \\
\hline $\begin{array}{l}\text { Pre- } \\
1968\end{array}$ & 132.5 & 236.380 & 20.6 & 36,750 & 5.0 & 8,920 \\
\hline TOTAL & 70.8 & 693,200 & 10.7 & 104,590 & 6.0 & 58,507 \\
\hline $\begin{array}{l}\text { GRAND } \\
\text { TOTAL }\end{array}$ & 47.7 & $1,376,680$ & 7.4 & 213,720 & 4.3 & 123,850 \\
\hline
\end{tabular}

NOTE: Emisston factor in Total column is weighted average of all factors. 
Emissions Due to Induced Development

In order to estimate emissions from induced development, a maximum of 2,700 new dwelling units was assumed to be necessary to house the maximum 2,700-person labor force. It was also assumed that the new dwelling units would be a mix of single family, multi-family, and moblle homes and that they would all be located in one town. While the estimate is undoubtedly an exaggeration of the construction impact, it will represent a worst case estimate from the standpoint of stationary source air pollutant emissions. It was also assumed that new commercial or institutional development would not be significant due to the temporary nature of the labor force.

Emission factors for new housing were obtained from a recent EPA publication "Growth Effects of Major Land Use Projects," September, 1976. The factors chosen combine an estimate of fuel consumption, based on heating degree-days, and emission factors for each type of fuel from EPA Publication AP-42. For this analysis, it was assumed that all fuel used for space and process heating in each dwelling unit would be fuel 011 . Table 15 lists the emission factors used in the study.

Table 15

Residential Heating Emission Factors

\begin{tabular}{|c|c|c|c|c|c|}
\hline & \multicolumn{5}{|c|}{ Pollutant } \\
\hline & Particulates & $\mathrm{SO}_{2}$ & $\mathrm{CO}$ & $\mathrm{HC}$ & $\mathrm{NO}_{x}$ \\
\hline $\begin{array}{l}\text { Space Heating } \\
\text { (grams/dwel1 ing unit- } \\
\text { heating degree-day-yr.) }\end{array}$ & 0.73 & $9.53 \mathrm{~S}$ & 0.36 & 0.21 & 0.86 \\
\hline $\begin{array}{l}\text { Process } \\
\text { (grams/dwel1ing unit- } \\
\text { year) }\end{array}$ & 1,090 & $15,436 \mathrm{~S}$ & 590 & 363 & 1,770 \\
\hline
\end{tabular}

Source: EPA, 1976. 
Table 16 shows estimated emissions using a heating degree-day factor of 5,000 (representative of the southwestern U.S.) and the 2,700 dwelling units.

Table 16

$$
\begin{gathered}
\text { Annual Emissions Due to Residential Space } \\
\text { and Process Heating } \\
\text { (Kg/Year) }
\end{gathered}
$$

\begin{tabular}{lccccc}
\hline & \multicolumn{6}{c}{ Pollutant } \\
\cline { 2 - 6 } & Particulates & $\mathrm{SO}_{2}$ & $\mathrm{CO}$ & $\mathrm{HC}$ & $\mathrm{NO}_{\mathrm{x}}$ \\
\hline Space Heating & 9,855 & 128,655 & 4,860 & 2,835 & 11,610 \\
Process & 2,943 & $\frac{41,677}{170,332}$ & $\frac{1,593}{6,453}$ & $\frac{980}{3,815}$ & $\frac{4,779}{16,389}$ \\
TOTAL & 12,798 & 170,8 & & & \\
\hline
\end{tabular}

Construction Emissions

Emissions due to construction of the fuel reprocessing facility would be the same as those estimated for the reference environment, which were summarized previously in Table 9.

Summary

All emlssions calculated for the boom-town environment analysis are summarized in Table 17. The emissions are divided into two categories -- growth inducement (motor vehicle and space heating) emissions and construction emissions. 


\section{Table 17}

Summary of Boom-Town Environment Emissions

(Kg/year)

\begin{tabular}{lcc}
\hline POLLUTANT & $\begin{array}{c}\text { CONSTRUCTION } \\
\text { EMISSIONS }\end{array}$ & $\begin{array}{c}\text { GROWTH-INDUCEMENT } \\
\text { EMISSIONS }\end{array}$ \\
\hline Carbon Monoxide & $2,045,829$ & $1,383,130$ \\
Hydrocarbons & 83,874 & 217,530 \\
Oxides of Nitrogen & 254,551 & 140,240 \\
Sulfur Dioxide & 14,941 & 170,332 \\
Particulates & 824,742 & 12,798 \\
\hline
\end{tabular}




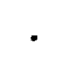




\section{AIR QUALITY IMPACTS - BOOM-TOWN ENVIRONMENT}

Particulates and Sulfur Dioxide

Both on-site construction activities and in-town residential heating will contribute to particulate and sulfur dioxide emissions. Fugitive dust at the construction site is estimated to be the major source of particulates, while residential space heating is the major source of sulfur dioxide. As in the previous analysis, motor vehicle particulate and $\mathrm{SO}_{2}$ emissions will be small in any particular area compared to the space heating emissions.

On-site construction emissions were modeled using the same methodology as in the reference environment analysis. Town-site emissions were assumed to be at ground level and represented by an area source with an area of $1 \mathrm{KM}^{2}$. The area source was placed approximately 5 miles northwest of the construction site.

Estimates of ground level particulate concentrations are shown in Figure 2. The area sources are marked by cross-hatched grids and the point source is marked by an "x." The isopleth values are particulate concentrations expressed as the $\mu \mathrm{g} / \mathrm{m}^{3}$ annual geometric mean. The model output is an annual arithmetic mean concentration; those concentrations were converted to annual geometric mean concentrations using statistical methods developed by Larsen (EPA, 1971) and air quality data from a typical midwest region (MPCA, 1974 and 1975). The concentrations presented are concentrations caused by construction activities and induced growth only; no background concentration is included.

As in the reference environment analysis, the maximum impact expected off the immediate construction site is a $30 \mu \mathrm{g} / \mathrm{m}^{3}$ annual 

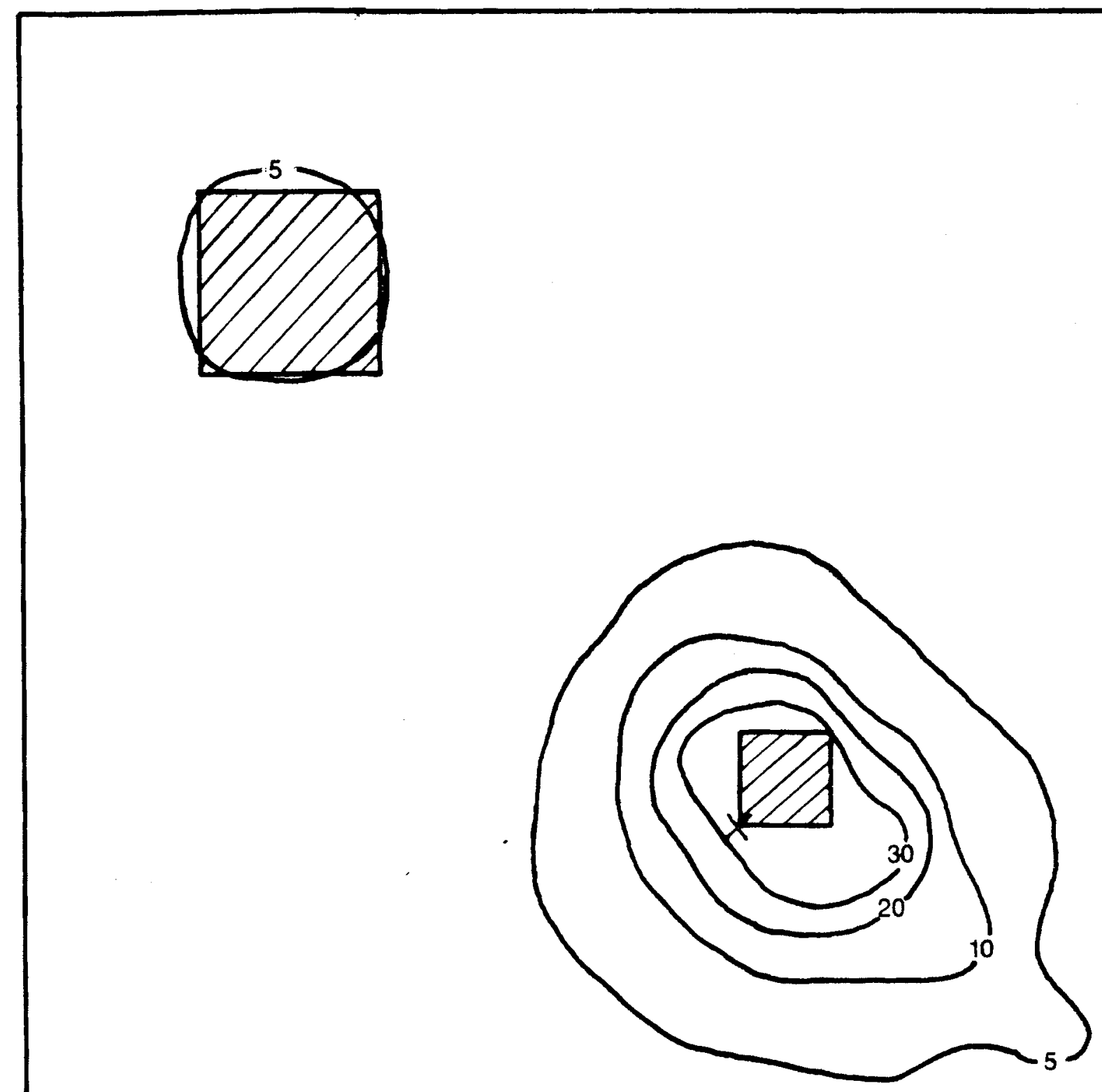

Scale 1 inch $=3280 \mathrm{ft}$. (1000 meters)

Figure 2.

Suspended Partlculate Concentrations due to Construction Stte Activfty and Induced Growth.

(Annual Geonetric Mean in $\mu g / m^{3}$ ) 
geometric mean increase. The maximum areal extent of the impact occurs about $3 \mathrm{~km}$ from the site boundary to the southeast, where a $5 \mu \mathrm{g} / \mathrm{m}^{3}$ increase in particulate concentrations occurs. Particulate impacts at distances further than $3 \mathrm{~km}$ from the site become negligible. Particulate concentration increases were found to exceed $100 \mu \mathrm{g} / \mathrm{m}^{3}$ annual geometric mean on the actual construction site.

Particulate concentration increases due to increased growth at the town site were estimated to reach a maximum of $5 \mu \mathrm{g} / \mathrm{m}^{3}$ at the site $i t$ self. Concentration increases beyond the boundaries of the town would be negligible.

Background particulate concentrations vary considerably in the southwest. Information collected from the State of New Mexico Environmental Improvement Agency (1977) indicates that particulate concentrations measured in large towns tend to be substantially higher than rural concentrations; however, the rural concentrations can be as high as $50 \mu \mathrm{g} / \mathrm{m}^{3}$ annual geometric mean. Given a background of $50 \mu \mathrm{g} / \mathrm{m}^{3}$, the $100 \mathrm{\mu g} / \mathrm{m}^{3}$ concentrations on the construction site would cause the $75 \mu \mathrm{g} / \mathrm{m}^{3}$ national standard to be exceeded. The $30 \mu \mathrm{g} / \mathrm{m}^{3}$ increases just off the site, but not off the property, would also cause the standard to be exceeded. Concentration increases at the town site are not expected to exceed any standards, although an annual standard of $60 \mu \mathrm{g} / \mathrm{m}^{3}$, existing in the states listed previously would be approached. Shortterm particulate concentrations can be estimated if the distribution of concentrations is assumed to be log-normal; however, the southwest particulate data collected was highly variable and did not appear to fit the log-normal assumption well. Therefore short-term concentrations are not estimated here.

The result of the $\mathrm{SO}_{2}$ model run is presented in figure 3. As was noted previously, $\mathrm{SO}_{2}$ concentrations due to construction activity would be very small. $\mathrm{SO}_{2}$ concentrations caused by induced growth, however, 


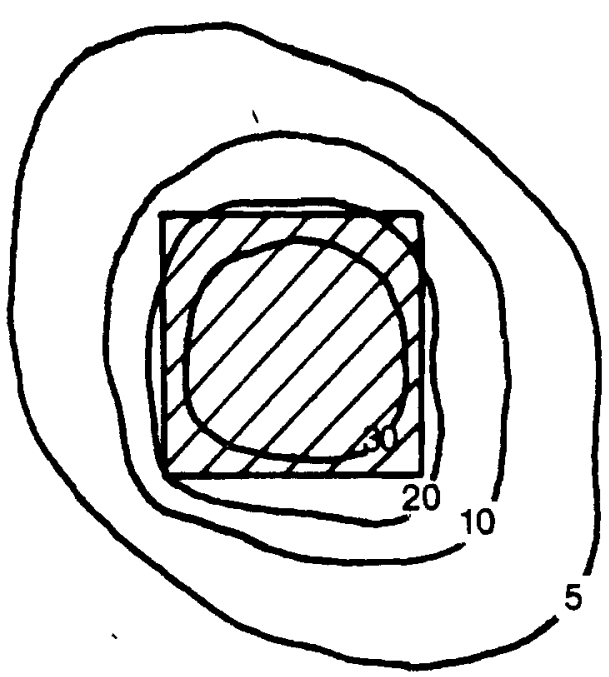

Scale 1 inch - $3280 \mathrm{ft}$. (1000 meters)

Figure 3.

Sulfur Dtoxide Concentrations due to Construction SIte Activity and Induced Growth.

(Annual Arithmetic Mean in $\mu \mathrm{g} / \mathrm{m}^{3}$ ) 
could be significant within the town site. A maximum annual average $\mathrm{SO}_{2}$ concentration increase of $37 \mu \mathrm{g} / \mathrm{m}^{3}$ was estimated due to residential space heating emissions. This concentration is well below the national standard of $80 \mu \mathrm{g} / \mathrm{m}^{3}$, however it could approach the national standard if a large background concentration of $\mathrm{SO}_{2}$ exists in the region -- an unlikely situation in a rural area unless there are existing mining or coal-burning operations.

Maximum short-term $\mathrm{SO}_{2}$ concentrations can be estimated using statistical methods developed by Larsen (EPA 1971). The maximum 24-hour $\mathrm{SO}_{2}$ concentration can be estimated using the formula:

$$
\text { where } \quad \begin{aligned}
& \text { Max } C=M g g^{2} .94 \\
& M a x C=\text { annual maximum 24-hour concentration } \\
& M g=\text { annual geometric mean } \\
& \mathrm{Sg}=\text { standard geometric deviation } \\
& \text { (assume } \mathrm{Sg}=2.0)^{*}
\end{aligned}
$$

Using (1), the maximum $37 \mu \mathrm{g} / \mathrm{m}^{3}$ annual average concentration would produce a 24-hour maximum of $225 \mu \mathrm{g} / \mathrm{m}^{3}$. This concentration is below the national 24-hour standard of $365 \mu \mathrm{g} / \mathrm{m}^{3}$, but could be approached if a large background exists.

\section{Carbon Monoxide}

The primary sources of carbon monoxide are motor vehicles and construction equipment. Impacts due to these sources were estimated previously in the reference environment analysis. Although $C O$ concentration increases are expected, no standards should be exceeded (Tabie 10).

\footnotetext{
*Average of $\mathrm{SO}_{2}$ standard geometric deviations taken at eight CAMP sites, as shown in Larsen (EPA 1971).
} 
Hydrocarbons and Nitrogen Oxides

Hydrocarbon and nitrogen oxide emissions will result from both motor vehicles and construction equipment. Neither pollutant lends itself well to estimation of impacts as was explained in the reference environment analysis. As before, it was decided that a comparison of total emissions generated by the construction force and construction activity with existing emissions in the area would serve as the most useful estimate of the impact. Of particular concern is the potential for formation of secondary pollutants, notably photochemical oxidant.

The total hydrocarbon emissions generated by both motor vehicle traffic and construction equipment was estimated to be $301,405 \mathrm{~kg}$ annually. Total nitrogen oxide emissions were estimated at $394,790 \mathrm{~kg}$ annually. These emissions would occur within about a 30 mile radius of the construction site.

In order to compare the construction-related emissions with existing emissions, a rural, isolated county was selected. Emissions were obtained through contact with a state air quality control agency (EIA, 1977). The total hydrocarbon emissions were $7,221,150 \mathrm{~kg}$ annually and the total nitrogen oxide emissions were $4,939,600 \mathrm{~kg}$ annually. Comparing project emissions with regional emissions yields a 4.2 percent project contribution to the county for hydrocarbon and an 8.0 percent contribution for nitrogen oxides. Both fractions are smal1, taking into account that the region is rural with a small emission rate at present. If, however, the region has topographical, meteorological, and emissions characteristics so that an oxidant problem exists, the construction emissions would require further analysis beyond this order of magnitude estimate to determine the impact.

Table 18 summarizes the maximum expected air quality impacts due to construction and growth inducement for the boom-town analysis. 
Table 18

Summary of Boom-Town Environment Impacts

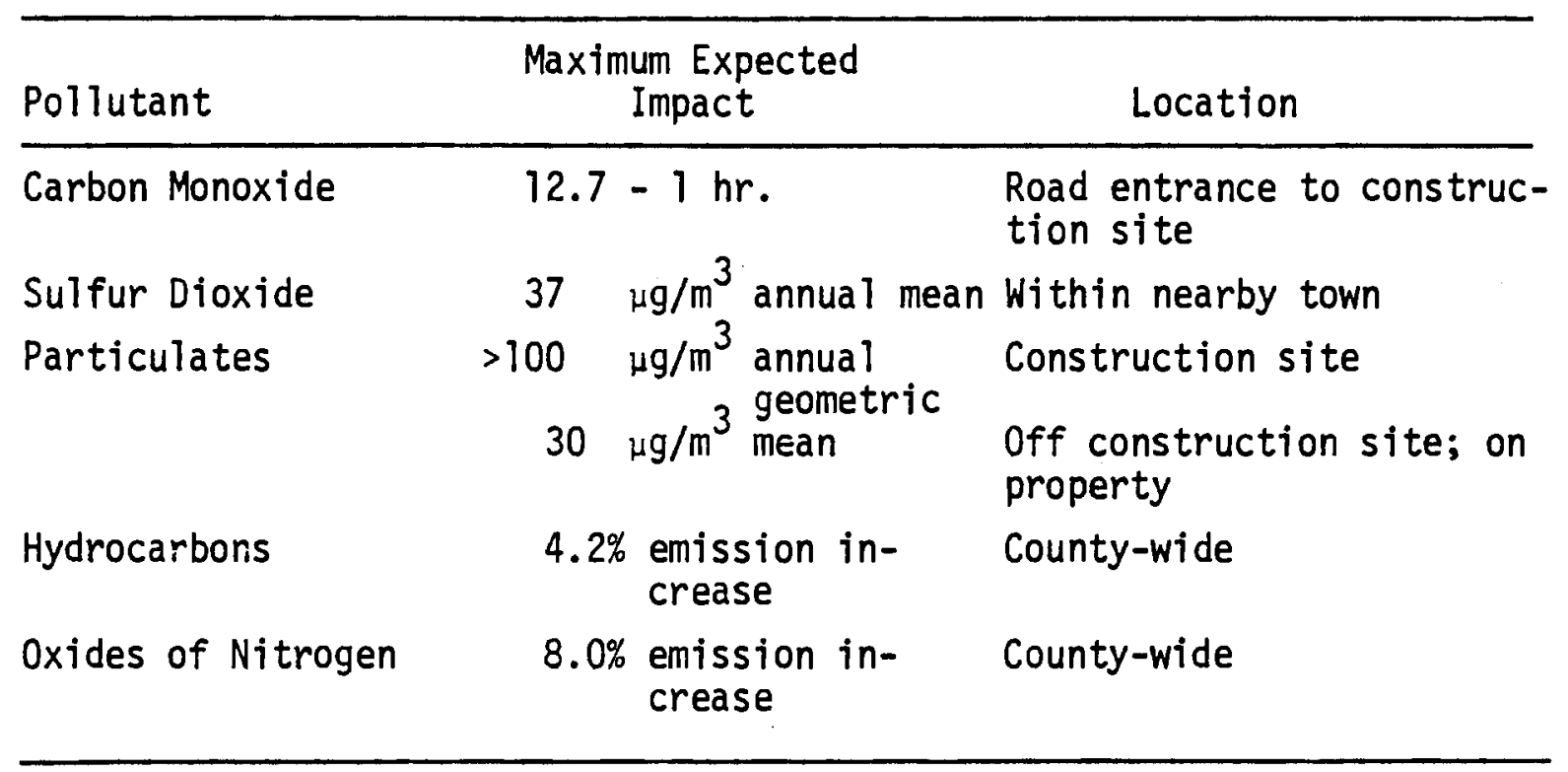


DISCUSSION 


\section{DISCUSSION}

A "worst case" approach was taken in the study of air quality impacts due to construction of a fuel reprocessing facility. Since complete information on construction activities and induced growth was not available, assumptions were made which would produce a worst case air quality impact to assess the order of magnitude of that impact. For example, the fuel reprocessing facility was chosen for analysis since it had the largest construction labor force of any facility. Construction of the other facilities would create a lesser impact than the fuel reprocessing facility.

Both the reference and boom-town analyses treated construction impacts in the same manner; however, their treatment of impacts due to growth inducement was different. The analysis of the reference environment was a worst case analysis of induced motor vehicle traffic. It assumed that the bulk of the labor force already resides in the area and would commute to the construction site, some long distances. This analysis assumed little or no in-migration. The boom-town analysis, on the other hand, assumed the entire labor force would migrate to the area, requiring new housing and generating new emissions. That analysis was therefore a worst case analysis of induced residential growth. In addition, it was assumed that the fuel burned for space heating would be 1 percent sulfur fuel oil.

Analysis of emissions due to construction activity was based on engineering estimates of labor force, fuel requirements, and land requirements. It is therefore a realistic estimate of the magnitude of impacts that can be expected and is identical for both scenarios. 
Estimates of socioeconomic impacts caused by construction, performed by Battelle Human Affairs Research Center, indicate that impacts will probably not be as extreme as assumed in this analysis. For example, the boom-town (or isolated environment) analysis assumed 100 percent inmigration; the figure would most likely be something less than 100 percent. The analysis also assumed that a new dwelling unit would be required for each member of the labor force; in reality existing towns in the area would probably have some vacancies to absorb the new labor force.

In conclusion, then, all phases of the analysis used a worst case approach. Based on the conservative modeling techniques applied and worst case emissions assumed, ambient concentrations of pollutants estimated by this study are an upper limit. Therefore actual concentrations, as might be obtained by on-site monitoring programs, are expected to be lower than those estimated here.

\section{Comparison of Facility Emissions}

As noted previously, all impacts identified were for the fuel reprocessing facility. Other facilities that could be built include a fuel storage facility, fuel fabrication facility, and a nuclear power plant. Table 19 presents a comparison of key characteristics of each facility which emission calculations are based on.

The characteristics of each facility in Table 19 can be normalized to the characteristics of the fuel reprocessing facility. The normalization scheme can then be used to estimate total emissions for each facility based on emissions calculated previously for the fuel reprocessing facility. For example, the ratio of land area between the fuel storage and fuel reprocessing facility is .67 . Therefore, fugitive dust particulate emissions for the fuel storage facility, which depends on land area cleared, will be about .67 of emissions calculated for the fuel 
Table 19

Comparison of Facility Characteristics

\begin{tabular}{llcccc}
\hline $\begin{array}{c}\text { Facility } \\
\text { Type }\end{array}$ & $\begin{array}{c}\text { Peak } \\
\text { Labor } \\
\text { Force }\end{array}$ & $\begin{array}{c}\text { Diesel Fuel } \\
\text { Consumption } \\
\text { (gallons) }\end{array}$ & $\begin{array}{c}\text { Gasoline } \\
\text { Consumption } \\
\text { (gallons) }\end{array}$ & $\begin{array}{c}\text { Concrete } \\
\text { Requirements } \\
\text { (cubic yds.) }\end{array}$ & $\begin{array}{r}\text { Land Area } \\
\text { Required } \\
\text { (acres) }\end{array}$ \\
\hline Fuel Reprocessing & 2,700 & $2,000,000$ & $2,600,000$ & 153,000 & 60 \\
Fuel Storage & 1,200 & $1,000,000$ & 700,000 & 30,000 & 40 \\
Fuel Fabrication & 1,200 & $1,200,000$ & 800,000 & 15,000 & 15 \\
Nuclear Power Plant & 1,700 & $3,900,000$ & $2,600,000$ & 250,000 & 34 \\
\hline
\end{tabular}

Source: Capital cost Estimate and Construction Impacts, Series of Reports by Bechtel, Inc. 
reprocessing facility. Estimated emissions for each facility are presented in Table 20. Total emissions of the fuel reprocessing facility represent the highest estimate for each category between the reference environment analysis and the boom-town analysis.

The data show that all facilities would have substantially lower emissions than the fuel reprocessing emissions, with the exception of the nuclear power plant. Fuel consumption for construction of the power plant would exceed that for the reprocessing facilities. Air quality impacts estimated for fuel consumption were very small for the reprocessing facility; they would also be small for the power plant despite the greater amount of fuel burned. All other facility impacts would be reduced by the percentages indicated.

Comparison of Diffusion Potential in Various Geographical Areas

The diffusion analyses conducted for particulates and $\mathrm{SO}_{2}$ in the reference environment used a joint frequency distribution of wind speed, direction, and stability typical of a midwestern location. Meteorological conditions at other locations could produce different diffusion potentials. In order to evaluate this effect, $x / Q$ values from different areas were compared and used to estimate maximum expected concentrations, based on the maximum expected concentrations calculated using the midwest data.

A comparison of maximum and average $x / Q$ values for eight different areas areas has been completed by PNL. (See Figure 4 for location of the eight sites.) The $x / Q$ values are listed in Table 21 . Maximum values are calculated for a fence-line distance of $1,135 \mathrm{~m}$ for any sector; average values are at the same distance but are an average of all sectors. The $x / Q$ values in Table 21 show 
Table 20

Comparison of Facility Emissions

\begin{tabular}{|c|c|c|c|c|c|c|c|c|c|c|}
\hline & \multicolumn{10}{|c|}{ Emissions $(\mathrm{Kg} / \mathrm{yr})$} \\
\hline & \multicolumn{5}{|c|}{ On-Site Construction } & \multicolumn{5}{|c|}{ Growth Inducement } \\
\hline & Particulates & $\mathrm{SO}_{2}$ & $\mathrm{CO}$ & $H C$ & ${ }^{N O}{ }_{x}$ & Particulates & $\mathrm{SO}_{2}$ & $\mathrm{CO}$ & $\mathrm{HC}$ & ${ }^{N} O_{x}$ \\
\hline Fuel Reprocessing & $8.2 \times 10^{5}$ & $1.5 \times 10^{4}$ & $2.0 \times 10^{6}$ & $8.4 \times 10^{4}$ & $2.5 \times 10^{5}$ & $2.4 \times 10^{4}$ & $1.7 \times 10^{5}$ & $2.7 \times 10^{5}$ & $4.3 \times 10^{5}$ & $2.5 \times 10^{5}$ \\
\hline Fuel Storage & $\begin{array}{c}5.3 \times 10^{5} \\
(65 \%)\end{array}$ & $\begin{array}{c}6.9 \times 10^{3} \\
(46 \%)\end{array}$ & $\begin{array}{c}5.6 \times 10^{5} \\
(28 \%)\end{array}$ & $\begin{array}{c}2.6 \times 10^{4} \\
(31 \%)\end{array}$ & $\begin{array}{c}1.1 \times 10^{5} \\
(44 \%)\end{array}$ & $\begin{array}{c}1.1 \times 10^{4} \\
(44 \%)\end{array}$ & $\begin{array}{l}7.6 \times 10^{4} \\
(44 \%)\end{array}$ & $\begin{array}{c}1.2 \times 10^{6} \\
(44 \%)\end{array}$ & $\begin{array}{c}1.9 \times 10^{5} \\
(44 \%)\end{array}$ & $\begin{array}{c}1.1 \times 10^{5} \\
(44 \%)\end{array}$ \\
\hline Fuel Fabrication & $\begin{array}{c}2.0 \times 10^{5} \\
(24 \%)\end{array}$ & $\begin{array}{c}8.2 \times 10^{3} \\
(55 \%)\end{array}$ & $\begin{array}{c}6.4 \times 10^{5} \\
(32 \%)\end{array}$ & $\begin{array}{c}3.0 \times 10^{4} \\
(36 \%)\end{array}$ & $\begin{array}{c}1.3 \times 10^{5} \\
(52 \%)\end{array}$ & $\begin{array}{c}1.1 \times 10^{4} \\
(44 \%)\end{array}$ & $\begin{array}{c}7.6 \times 10^{4} \\
(44 \%)\end{array}$ & $\begin{array}{c}1.2 \times 10^{6} \\
(44 \%)\end{array}$ & $\begin{array}{c}1.9 \times 10^{5} \\
(44 \%)\end{array}$ & $\begin{array}{c}1.1 \times 10^{5} \\
(44 \%)\end{array}$ \\
\hline Nuclear Power Plant & $\begin{array}{c}5.1 \times 10^{5} \\
(63 \%)\end{array}$ & $\begin{array}{r}2.7 \times 10^{4} \\
(180 \%)\end{array}$ & $\begin{array}{r}2.1 \times 10^{6} \\
(105 \%)\end{array}$ & $\begin{array}{r}9.7 \times 10^{4} \\
(115 \%)\end{array}$ & $\begin{array}{r}4.4 \times 10^{5} \\
(176 \%)\end{array}$ & $\begin{array}{c}1.5 \times 10^{4} \\
(63 \%)\end{array}$ & $\begin{array}{c}1.1 \times 10^{5} \\
(63 \%)\end{array}$ & $\begin{array}{c}1.7 \times 10^{6} \\
(63 \%)\end{array}$ & $2.7 \times 10^{5}$ & $\begin{array}{c}1.6 \times 10^{5} \\
(63 \%)\end{array}$ \\
\hline
\end{tabular}

NOTE: Percentages in parentheses represent the percentage of each facility's emissions to those of fuel reprocessing facility emissions. 
Table 21

Comparison of $x^{1 Q}$ Values at Eight Sites

Max. at Avg. at

\begin{tabular}{|c|c|c|c|c|}
\hline Site & $1135 \mathrm{M}$ & $1135 \mathrm{M}$ & Max/Site A Max. & Avg/Site \\
\hline A & $2.6 \times 10^{-6}$ & $1.6 \times 10^{-6}$ & 1.0 & 1.0 \\
\hline B & $9.6 \times 10^{-6}$ & $4.4 \times 10^{-6}$ & 3.7 & 2.75 \\
\hline C & $1.5 \times 10^{-5}$ & $4.7 \times 10^{-6}$ & 5.8 & 2.9 \\
\hline D & $2.9 \times 10^{-6}$ & $1.6 \times 10^{-6}$ & 1.1 & 1.0 \\
\hline E & $3.5 \times 10^{-6}$ & $2.4 \times 10^{-6}$ & 1.3 & 0.9 \\
\hline $\mathrm{F}$ & $3.2 \times 10^{-6}$ & $2.4 \times 10^{-6}$ & 1.2 & 1.5 \\
\hline G & $4.0 \times 10^{-6}$ & $2.4 \times 10^{-6}$ & 1.5 & 1.5 \\
\hline H & $5.3 \times 10^{-6}$ & $2.2 \times 10^{-6}$ & 2.0 & 1.4 \\
\hline
\end{tabular}

Note: Meteorological data from Site A were used in the diffusion estimates in this study.

Table 22

Comparison of Diffusion Potential and Maximum Expected

Concentrations for Various Geographical Areas

\begin{tabular}{|c|c|c|}
\hline & Construction & Growth Inducement \\
\hline Area & $\begin{array}{l}\text { Max. Off-Site Geometric Mean } \\
\text { Particulate Conc. }\left(\mathrm{\mu g} / \mathrm{m}^{3}\right)\end{array}$ & $\begin{array}{c}\text { Max. Annua] Avg Conc. of } \\
\mathrm{SO}_{2}\left(\mathrm{\mu g} / \mathrm{m}^{3}\right.\end{array}$ \\
\hline A & 30 & 37 \\
\hline B & 111 & 101 \\
\hline C & 174 & 107 \\
\hline D & 33 & 37 \\
\hline E & 39 & 33 \\
\hline$F$ & 36 & 55 \\
\hline G & 45 & 55 \\
\hline$H$ & 60 & 52 \\
\hline
\end{tabular}




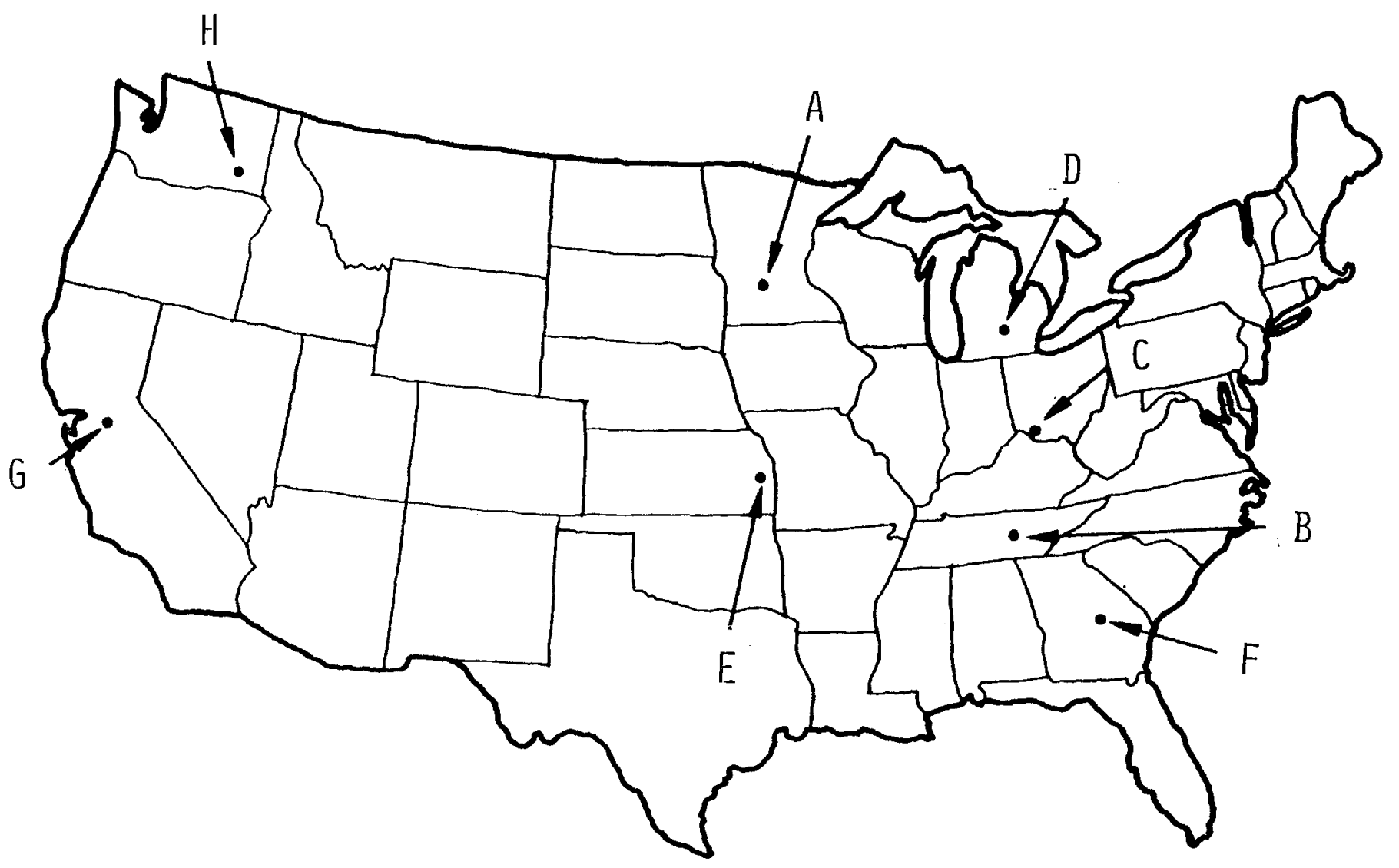

Figure 4.

Location of Sites for Diffusion Potential Comparison. 
that the lowest value is for the site whose meteorological data was used for the study. Therefore, one would expect higher concentrations at other sites evaluated.

The ratios in Table 21, when applied to previously calculated concentrations, can be used to estimate concentrations in other areas. The maximum annual geometric mean particulate concentration estimated off the immediate construction site was $30 \mu \mathrm{g} / \mathrm{m}^{3}$. The maximum annual ayerage $\mathrm{SO}_{2}$ concentration calculated was $37 \mathrm{\mu g} / \mathrm{m}^{3}$, within the hypothestzed town. Table 22 lists estimated maximum concentrations for areas with different diffusion potentials.

A short explanatory note about the data included in Table 22: the construction particulate concentration was a maximum concentration calculated for a particular sector; therefore the ratio used was the Max./Site A Max. ratio which takes into account differences in wind speeds and persistence in any given wind direction. The $\mathrm{SO}_{2}$ concentration, on the other hand, was calculated at a receptor within the area source, where wind persistence in any given sector would make little or no difference in the calculated concentration. The magnitude of the concentration would therefore be dependent primarily on wind speed; consequently the Avg./Site A Avg. ratio was used to estimate $\mathrm{SO}_{2}$ concentrations.

It can be seen that substantial particulate and $\mathrm{SO}_{2}$ concentrations could result in areas with more restricted diffusion potential. A 174 $\mu \mathrm{g} / \mathrm{m}^{3}$ particulate geometric mean concentration off the construction site but on the property was estimated for the $C$ site, far above the annual standard. Impacts off the $24 \mathrm{~km}^{2}$ property would still be minimal, 
however. Particulate concentrations at several other construction sites would also exceed the annual standards.

$\mathrm{SO}_{2}$ concentrations could reach $107 \mu \mathrm{g} / \mathrm{m}^{3}$ within the hypothesized town, using the site $C$ meteorological data. This concentration exceeds the $80 \mathrm{\mu g} / \mathrm{m}^{3}$ annual standard. $\mathrm{SO}_{2}$ concentrations at the B Site would also exceed the standard. 
REFERENCE LIST 


\section{REFERENCE LIST}

Bay Area Air Pollution Control District, Guidelines for Air Quality Impact Analys is of Projects, San Francisco $\overline{C A}, 1975$.

Bechtel, Inc. Capital Cost Estimate and Construction Impacts of Waste Management Facilities. Series of reports dealing with a fuel Reprocessing Plant, Independent Spent Fuel Storage Facility, Mixed Oxide Fuel Fabrication Plant, and a LWR Nuclear Power Plant. Prepared for Battelle Northwest Laboratories, San Francisco, CA, January-February, 1977.

California Department of Transportation. Mathematical Approach to Estimating Highway Impact on Air Quality, Sacramento, CA, 1972.

Minnesota Pollution Control Agency. Minnesota Air Quality Data - 1973, Rosewel1, MN, 1975.

- Minnesota Air Quality Data - 1974, Rosewe11, MN, 1975.

National Cooperative Highway Research Program, Report 24. Urban Travel Patterns, Washington, D.C., 1966.

New Mexico Environmental Improvement Agency. Prel Iminary Sumary of Statewide Air Quality Data, 1973-1976, Santa Fe, New Mexico, 1977.

PEDCo Environmental Specialists, Inc. Investigation of Fugitive Dust Sources and Control, Cincinnati, Ohio, 1974.

U.S. Environmental Protection Agency. Workbook of Atmospheric Dispersion Estimates, Research Triangle Park, N.C., 1970.

- A Mathematical Model For Relating Air Quality Measurements to Air Quality Standards, Research Triangle Park, N.C., 1971.

- Compilation of Air Pollutant Emission Factors, Second Editton, Research Triangle Park, N.C., 1972.

- User's Guide For the Climatological Dispersion Model, Research Trtangle Park, N.C., 1973.

- Compllation of Air Pollutant Emission Factors, Supplement No. 3, Research Triangle Park, N.C., 1974.

- Compilation of Air Pollutant Emission Factors, Supplement No. 4, Research Triangle Park, N.C., T975a. 
- Compllation of Air Pollutant Emission Factors, Supplement No. 5 , Research Triangle Park, N.C., 1975b.

- Growth Effects of Major Land Use Projects, Volume III, Summary, Research Triangle Park, N.C., 1976.

Western Section Institute of Traffic Engineers, Trip Generation, 1967. 
ACKNOWLEDGMENTS 


\section{ACKNOWLEDGMENTS}

The authors wish to thank Michael Mickland and Christopher Cluett of Battelle Human Affairs Research Center for helpful information provided in this report. In addition, appreciation is extended to 0 . B. Shipler of Pacific Northwest Laboratory for data related to $x / Q$ values. 


\section{DISTRIBUTION}

No. of

Copies

OFFSITE

A. A. Churm

DOE Patent Division

9800 S. Cass Avenue

Argonne, IL 60439

27 DOE Technical Information Center

ONSITE

DOE Richland Operations Office

H. E. Ransom

15 Pacific Northwest Laboratory

I. C. Nelson

W. F. Sandusky (3)

D. G. Watson

J. B. Brown

R. D. Glenn

J. G. Droppo

Technical Information (5)

Publishing Coordination (2) 


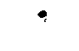

